\title{
Educational strategies to strengthen digital competencies in Colombian aeronautics instructors
}

\section{Estratégias educacionais para fortalecer competências digitais em instrutores da aeronáutica colombiana}

\author{
Carlos Alberto Suárez Robledo¹, Lorena Yadira Alemán de la Garza², \\ Marcela Georgina Gómez Zermeño ${ }^{3}$ \\ Special Administrative Unit of Civil Aeronautics, Bogota, Colombia. <A01316879@itesm.mx> \\ 2 Tecnológico de Monterrey, Monterrey, México. <lorena.aleman@itesm.mx> \\ ${ }^{3}$ Tecnológico de Monterrey, Monterrey, México.<marcela.gomez@item.mx>
}

\begin{abstract}
This research aimed to establish the educational strategies that contribute to the strengthening of digital competencies of teachers from the Center of Aeronautical Studies of Colombia's Civil AgencyAviation Authority and the activities that promote blended learning courses. The study adopted a quantitative approach with a non-experimental descriptive design to analyze the use of Information and Communication Technologies at the Center of Aeronautical Studies. The results of this research indicate the need for specific policies focused on the implementation of technologies and a virtual platform for the administration of courses, to strengthen the human and technical resources for the blended learning courses and to promote the digital competencies.
\end{abstract}

KEYwords: Digital competencies; Aviation training; Blended learning.

\section{RESUMO}

Esta pesquisa tem como objetivo estabelecer estratégias educacionais que contribuam para o fortalecimento de competências, no meio digital, de professores do Centro de Estudos Aeronáuticos da Aeronáutica Civil da Colômbia e atividades para promover cursos de aprendizagem combinada. Este estudo utilizou um método quantitativo e um não experimental, descritivo, para analisar o uso de Tecnologias de Comunicação e Informação no Centro de Estudos Aeronáuticos. Os resultados desse estudo indicam a necessidade de políticas específicas para implementação de tecnologias e uma plataforma virtual para a administração de cursos, para reforçar os recursos humanos e técnicos para cursos de aprendizagem combinada e o desenvolvimento de competências digitais.

PAlAVRAS-CHAVE: Competências digitais; Treinamento de aviação; Aprendizagem combinada.

Pontifical Catholic University of Rio Grande do Sul Porto Alegre, RS, Brazil

Editor

Thaís Russomano

Microgravity Centre PUCRS, Brazil

Executive Editor

Rafael Reimann Baptista

Faculdade de Educação Física e Ciências do Desporto, PUCRS, Brazil

e-ISSN: $2179-703 X$
Corresponding Author:

Marcela Georgina Gómez Zermeño

<marcela.gomez@itesm.mx>

Received: December 15, 2015 Accepted: December 25, 2015

(C) 2015 EDIPUCRS 


\section{Introduction}

The International Civil Aviation Organization (ICAO) has focused its efforts on the design and execution of regulatory, procedural and technical strategies to guarantee safe and efficient air traffic operations in consideration of the risks involved in these activities [1]. According to the ICAO [1], 3 out of 4 aerial incidents in the world are related to the human factor. To reduce the rate of accidents, the ICAO has implemented a training approach called TRAINAIR, based on the instructional design practices of the American Telephone and Telegraph Company (AT\&T) during the 1960s, the International Telecommunication Union (ITU) in 1975, and the TRAIMAR program by the United Nation's Conference for Commerce and Development for port staff training [2].

The TRAINAIR method of aviation instruction relates to the technical and rational approach of educational technology, which is founded on "a group of sufficiently consistent and solid knowledge on how to organize the variables that influence in the learning process in order to plan instructional environments aimed to achieve educational goals" [3]. This approach has been criticized for being based on a reductionist vision of the learning process derived from behaviorism [3]. Despite these criticisms, the Centers for Civil Aviation Training and the Centre for Aviation Studies of Colombia have continued to develop their courses using the TRAINAIR methodology. However, as a consequence of the growth of civil aviation driven by globalization, the advances of the industry, tourism, and the incorporation of information and communications technologies (ICT) to aeronautical and airport services, the TRAINAIR model has been in crisis [4, 5]. This change in the aviation scenario caused the ICAO to recommend that the different organizations to transform their instructional processes towards a competency-based approach [6].

Although the worldwide growth of civil aviation has been observed since the 1970s, the industry has witnessed many fluctuations over the years. According to the ICAO [7] in 2007, the civil aviation industry accounted for $8 \%$ of global Gross Domestic Product. An estimated increase of $46 \%$ is expected to occur between 2010 and 2030, doubling the number of flights to 48.7 million. Even taking into account the growth in staff outsourcing and staff replacement by automation technologies, this implies an increase in the number of people working directly for international civil aviation will take place, growing to approximately 12.1 million employees [8].
This prospective growth in international civil aviation is acknowledged in the strategic documents and initiatives of the ICAO. Among these are two fundamental documents related to "The Operational Concepts of Global Air Traffic" [9] and the "Global Air Navigation Plan" (ICAO, 2007b). The first addresses the vision of civil aviation, whereby the 190 pieces of controlled airspace regions in the world will be integrated by the year 2025, so that aircraft can flow without technological, technical or communication barriers [9]. The second document details the strategic plan to make this vision possible, covering all the necessary requirements for air traffic management (ATM), technologies for the communication, navigation and surveillance (CNS) system, and other factors related to human and instructional needs [10].

The current scenario poses new challenges for the training processes of technical staff, which are classified into three main categories: basic instruction, instruction for implementers of the ATM/CNS system, and specific tasks instruction [10]. Basic instruction aims to offer "the basic knowledge of automation, digital and satellite communications, and computer networks, to provide all civil aviation personnel the required skills, prior to receiving the specific training they need for certain tasks" [10]. Training for implementers of the ATM/CNS system is aimed at the management levels thatthat are responsible for planning the implementation of the system and, finally, instruction for the specific tasks focuses on personnel who operate and maintain the system [10].

A blended learningtraining course has been developed by the Center of Aeronautical Studies (Centro de Estudios Aeronáuticos, or CEACEA) in order to provide training, where teachers must first study the theory and then visit the CEA to experience a simulation with the help of technological resources [11]. This course is conducted through use of a compact-disc resource and tutored through email and telephone contact. In this context, the implementation of an educational platform technology could be a strategy to improve the courses and training.

This research aimed to identify the current state of the policies of the CEA of Colombia's Civil Aviation Authority (Aerocivil) Agency regarding the use of ICT in the teaching-learning procedure, and to evaluate the digital competencies of CEA teachers in the training processes, seeking to establish educational strategies and actions to promote the development of digital competences in CEA educators. Thus, a quantitative approach with a non-experimental descriptive design was performed to analyze the use of information 
and communication technologies at the Center of Aeronautical Studies.

\section{Literature Review}

\subsection{Educational innovation, the role of teachers and Information and Communication Technologies}

Although the definition of innovation varies, an educational innovation is characterized by a planned transformation in educational practice and the elements forming part of that context, in order to fulfill the learning goals and needs of students so as to improve education quality and to face the challenges of modern society [12-14]. Rimari [12] proposed that educational innovation consists of a significant qualitative transformation, not just making simple adjustments; they introduced something not necessarily new but resulting in a breakthrough. The author also considers that innovation is more related to the enhancement of educational institutions and actors with the simple implementation of new educational concepts, programs or technology tools.

There are several reports showing how educational innovation can be successfully implemented. SEffective experiences of educational innovation can be seen in reports from the Private University of Santa Cruz de la Sierra (UPSA) in Bolivia and the Monterrey Institute of Technology and Higher Education (ITESM) in Mexico, where the institutions pointed out various factors required for innovation, such as the human intellect provided by principals, teachers and students, who must have a systematic vision, flexibility, creativity, and communication and collaborative work skills, to be able to solve problems and develop self-assessment [14]. The processes of educational innovation depend on the role of the teachers, who must become leaders of change and transformation of beliefs, habits, and values, to establish a vision of reflection, knowledge generation and the construction of learning environments $[15,16]$.

ICTs have great potential for educational innovation, however, this requires a transformation of the pedagogical models and practices of teachers. Models should focus on teaching and encouraging active methodologies, and on the improvement of student skills through the mediation or facilitation of teaching, supported by ICT. To meet this challenge, teachers must strengthen the ability of self-learning and skills in the use of ICTs related to the search, development, and dissemination of information, web browsing and creation of learning communities [17-19].

Since the beginning of the 20th century, both industry and the military sector have promoted the development of structured training courses, based on educational technology, in order to achieve efficiency in work performance. Educational technology has been studied in relation to behavioral theories, the positivist scientific method and management theories, which became the focus for employment training in areas such as port services, civil aviation and communications. With the paradigms of science, transformations have occurred in technology education and in the competency-based approach, which is characterized by promoting a comprehensive development of human beings in order to perform and encourage values and morals [20-23].

In traditional and distance-learning settings, the use of ICT has generated positive impact, both in management and practices. E-learning has become an alternative for job training or postgraduate education. Its success, however, depends on the aptitude of the individual for self-motivation, self-regulation and time management to achieve the course objectives. On the other hand, the use of ICT for job training has been promoted by companies in order to achieve the benefits of increased productivity, professional development, promotion of institutional values, and transformation of attitudes and skills [24]. The efforts of the authorities, educational institutions and companies to promote the use of ICT in education has not reached the expected goals, not only for the financial and technical challenges that are present, but primarily because "many teachers lack sufficient computer skills to feel comfortable, or specific training to use the new resources in the classroom" [25]. Given the necessity of technology training, UNESCO designed the project "UNESCO ICT Competency Standards for Teachers", through which they present the basic knowledge of ICT, awareness and knowledge generation, contemplated for strengthening the skills of teachers and "to improve the quality of the education system, and contribute to economic and social development" [26].

\subsection{Quality of education and ICT competencies}

In the Western world, the term quality has been around since ancient times and was studied by philosophers like Aristotle, Kant, and Hegel, who understood it as the essential characteristic of things and/or people. Nonetheless, it is only following consolidation of the industrial society that the term has becoame of great significance, being used to evaluate or judge products or services in comparison to others of the same nature [27]. The concepts of quality have transferred from the service industry to 
the educational field. Its purpose is to validate the system's vision, policies, practices, contents, roles, infrastructure, and resources, in order to fulfill the requirements for universal and equal access [27-29].

During the last decades, actions have been taken in order to develop the requirements that must be gathered by educational systems, programs, and institutions. Likewise, indicators have been established to facilitate the evaluation of quality and equity $[30,31]$. As in many countries, Colombia's Ministry of National Education (Ministerio de Educación Nacional, or MEN) defined the "National System of Education Indicators" for primary and secondary education, based on the model developed by the Organization for Economic Cooperation and Development (OECD) and the Regional Education Indicators Project promoted by UNESCO. Colombia also established a mandatory accreditation process for higher education, through which institutions must meet quality standards, focusing on the processes of institutional self-evaluation and verification by academic peers [31-33]. Furthermore, and in order to provide a strategy for the development of ICT skills among teachers and their use in educational practices, MEN established the policy called "Route of appropriation of ICT in Teacher Development" where standards and indicators are determined.

Two different purposes are present in the current regulations for evaluation of the quality of education. The most prevalent is driven by the dominant liberal ideology of globalization, aimed at strengthening the logical-mathematical, communication, and technical competencies in order to achieve integration of the labor market and knowledge industries. The alternative tends to foster the formation of critical awareness of the world context, and to promote citizen participation and democracy as a strategy for the transformation of society, oriented towards justice, equity and solidarity [34,35].

\section{Method}

Selection of the research method requires consideration of the epistemological paradigms, context, objectives and ability to carry out the investigation [36]. This research study selected a quantitative approach with a descriptive design, given that its purpose was to assess the development of digital skills in accordance with the literature review. Similarly, a non-experimental and transactional design was used as data was collected at a single moment, without alteration of the phenomena under study [36].

The CEA is located in Bogota, the capital city of Colombia, which is the largest educational and cultural center in the country and home to major industries. Their task as a specialist training center is to provide courses to air navigation technical staff in airports and air traffic control centers throughout the country [37]. The educational and administrative staffss are trained through academic meetings, which are held annually in the CEA, under guidelines established by the ICAO [37].

The population for this study was composed of 111 permanent staff working at the CEA, distributed as follows: 33 staff personnel including 6 managerial officials, and 78 services providers including 31 teachers. A nonprobability sample was adopted to meet the aim of inquiring about ICT use policies of teachers and students, thus, 5 managerial officials were selected and 31 teachers who provided services for air navigation training.

Valenzuela \& Flores [38] indicate the importance of an instrument being appropriate to the research objectives. Therefore, a semi-structured interview was designed for the managerial staff, created with five questions related to ICT policies and promotion. The instrument applied to the participating teachers for analysis of digital competencies was adapted from the questionnaire provided by Prendes, Castañeda and Gutierrez [39], to measure the degree of competency development for the technical, technological, pedagogical, communicative and ethical aspects, resulting in a total of 50 items. The instrument questions were built using a Likert scale with scores of 1-5. The data obtained from the survey was processed using the Statistical Package for the Social Sciences (SPSS). Cronbach's alpha analysis yielded a result of 0.812, which demonstrates coherence and high internal consistency [36]. Lastly, a focus group was formed including a member of the managerial staff and five teachers, chosen randomly from the participating sample.

\section{Results analysis}

Pilot tests were first conducted and the instruments adjusted accordingly, after which, the CEA managerial staff interviews and 50-item teacher survey of the CEA proceeded, the50-item and the focus group meeting including members of both populations was held.

Presentation of the results is shown as follows:

- Policy for use of ICT in the CEA.

- Digital competencies in the teaching at the CEA.

- Strategies and actions to promote the use of ICT in the training processes of the CEA. 


\subsection{Policy for use of ICT in the Center of Aeronautical Studies}

Interviews were conducted with the 5 members of the managerial staff to determine the CEA policies in relation to the use of ICT. The interviewees agreed that no specific policy regarding the use of technology existed. They described the general policy of the center in two main aspects: acquisition and implementation of informatics technology, reflected in the Strategic Plan of Information Technology Acquisition; and security information in the Model of Information Security in the Aerocivil.

1) The Strategic Plan determines the type of equipment and programs required in the different areas of the Aerocivil and highlights the needs related to the company mission and services.

2) The Model of Information Security in the Aerocivil, as indicated by the participants, is comprised of policies, regulation, standards and roles adopted from resolution 04228, dated August 2nd, 2012 [40].

The overall objective of the policy is to manage information effectively and safely to ensure confidentiality, integrity and availability to contribute to the achievement of institutional goals. The specific policies refer to the exclusive use of information for the development of activities and for the confidentiality of information.

Interviewees reported that the center currently has 22 specialized information systems, but only the Academic Information System is related to the CEA. Management, administrative and teaching personnel confirmed they had access to computers and the Intranet under the security policy conditions. In terms of limitations, the participants reported the computers as being obsolete, with limited program use, and having restricted access to education portals and Internet files. The participants agreed that current limitations do not to encourage the use of ICT in learning processes or online courses. The results of the survey are shown in Table 1.

\subsection{Digital Competencies of the teachers of the Center of Aeronautical Studies}

The results obtained from application of the 50 -item survey are presented in this section. The teaching staff 50 -item are presented in which the teachersprovided their opinions using a Likert scale regarding the development of digital competences in the general, technical and technological, pedagogical, communicative and ethical aspects.
Table 1. Limitations for the development of digital competencies - survey results

\begin{tabular}{ll}
\hline \multicolumn{1}{c}{ Categories } & Level \\
\hline Obsolete computers & High \\
Use of programs different from Office & High \\
Use of e-mail (Management staff) & Low \\
Use of e-mail (Administrative staff) & Medium \\
Use of e-mail (Teaching staff) & Medium \\
Internet access (Management staff) & Low \\
Internet access (Administrative staff) & Medium \\
Internet access (Teaching staff) & Medium \\
Internet access for students & High \\
Internet access in classrooms and laboratories & High \\
Internet access in libraries & High \\
Access to educational platforms & High \\
Wi-Fi access & High \\
Documents download & High \\
\hline
\end{tabular}

The characteristics of the teachers were firstly collected, revealing that $25.8 \%$ of them were aged between 36 and 45 years, while $74.2 \%$ were older than 46 years. A gender difference was observedshown, with 28 male teachers being maleand 3 female teachers, demonstrating a predominance of men working in the aviation area. In relation to the number of years of experience in the field of aviation, $80.8 \%$ of the teachers had worked at the CEAthere for less than 10 years and $71 \%$ stated they also worked in other educational institutions.

The first results category relates to technical and technological skills, which is divided into information retrieval (Table 2), document creation and editing (Table 3), Internet use (Table 4), and use of the tools provided by the Aerocivil (Table 5).

According to the results, the most developed skills were files recovery $(74.2 \%)$, word processor use (90.3\%), graphic organizers use $(74.2 \%)$, spreadsheet use (83.9\%) Internet browser (93.5\%) and e-mail (90.32\%) use. The less developed skills were creating pivot tables $(32.3 \%)$, modification of databases (19.4\%), web page development (6.5\%), blog creation (32.3\%), online books use (32.5\%) and use of platforms like Moodle or Blackboard (32.3\%). This indicates the provision of equipment and programs should be a first step to open the possibility of transforming the pedagogical model and practices of teachers [17].

In regard to educational aspects, participants expressed the development of competencies to be related to the use of computers in the classroom 
(93.55\%), encouraging students to do their tasks on computers $(74.19 \%)$, and to the use of multimedia presentations $(67.74 \%)$. Lastly, it is noted that approximately $30 \%$ of teachers did not make use of multimedia presentations to support their teaching practice. The following categories analyzed through the survey were pedagogical (Table 6), communication (Table 7) and ethical (Table 8) aspects.

Table 2. Technical and technological aspects - Information retrieval

\begin{tabular}{|c|c|c|c|c|}
\hline Competency & Mean & Mode & $\begin{array}{l}\text { Standard } \\
\text { deviation }\end{array}$ & $\begin{array}{l}\text { Teachers with } \\
\text { competency }\end{array}$ \\
\hline Installation of hardware such as hard disk, video cameras, and sound equipment. & 3.48 & 5.00 & 1.71 & $54.8 \%$ \\
\hline Search and retrieve files from hard disk, CD or USB drive. & 4.16 & 5.00 & 1.07 & $74.2 \%$ \\
\hline Solution of internet or computer problems. & 4.39 & 5.00 & 0.72 & $87.1 \%$ \\
\hline $\begin{array}{l}\text { Knowledge about computer speed and compatibility to save, organize and retrieve } \\
\text { information. }\end{array}$ & 4.06 & 5.00 & 0.96 & $71.0 \%$ \\
\hline Knowledge about compatibility of computers, operating systems and software. & 3.90 & 4.00 & 1.11 & $71.0 \%$ \\
\hline
\end{tabular}

Table 3. Technical and technological aspects - document creation and editing

\begin{tabular}{|c|c|c|c|c|}
\hline Competency & Mean & Mode & $\begin{array}{l}\text { Standard } \\
\text { deviation }\end{array}$ & $\begin{array}{l}\text { Teachers with } \\
\text { competency }\end{array}$ \\
\hline Creation and editing of documents with word processors & 4.61 & 5.00 & 0.84 & $90.3 \%$ \\
\hline Organization of data in graphic organizers & 4.13 & 5.00 & 0.99 & $74.2 \%$ \\
\hline Construction of conceptual maps in specialized software & 3.32 & 4.00 & 1.40 & $54.8 \%$ \\
\hline Creation and editing of multimedia slideshows & 4.16 & 5.00 & 1.00 & $71.0 \%$ \\
\hline Include audio clips in multimedia slideshows & 3.39 & 3.00 & 1.26 & $48.4 \%$ \\
\hline Design of images with editing software & 3.68 & 4.00 & 1.22 & $61.3 \%$ \\
\hline Creation and editing of spreadsheets & 4.19 & 4.00 & 0.87 & $83.9 \%$ \\
\hline Design and creation of pivot tables & 2.87 & 3.00 & 0.99 & $32.3 \%$ \\
\hline Design, creation and modification of databases & 2.61 & 3.00 & 0.95 & $19.4 \%$ \\
\hline Design and creation of web pages & 1.87 & 1.00 & 1.02 & $6.5 \%$ \\
\hline
\end{tabular}

Table 4. Technical and technological aspects - Internet use

\begin{tabular}{|c|c|c|c|c|}
\hline Competency & Mean & Mode & $\begin{array}{l}\text { Standard } \\
\text { deviation }\end{array}$ & $\begin{array}{l}\text { Teachers with } \\
\text { competency }\end{array}$ \\
\hline Use of Google, Yahoo or browsers & 4.71 & 5.00 & 0.69 & $93.5 \%$ \\
\hline Use of research engines & 4.48 & 5.00 & 1.03 & $90.3 \%$ \\
\hline Configuration of antivirus software to analyze internet files & 3.68 & 5.00 & 1.40 & $61.3 \%$ \\
\hline Use of digital libraries for information research & 3.23 & 4.00 & 0.99 & $51.6 \%$ \\
\hline Identifies open software and copyright & 2.81 & 4.00 & 1.19 & $38.7 \%$ \\
\hline Participates in web conferences & 2.94 & 4.00 & 1.24 & $48.4 \%$ \\
\hline Uses online tutorials for problem solution & 2.74 & 4.00 & 1.15 & $35.5 \%$ \\
\hline Knowledge about blogs creation & 3.13 & 3.00 & 1.28 & $32.3 \%$ \\
\hline Use social networks such as Facebook or Twitter & 3.68 & 5.00 & 1.58 & $67.7 \%$ \\
\hline Knowledge about Learning Management Systems or educational platforms & 2.68 & 1.00 & 1.62 & $32.3 \%$ \\
\hline
\end{tabular}

Table 5. Technical and technological aspects - available tools in the Aerocivil

\begin{tabular}{|c|c|c|c|c|}
\hline Competency & Mean & Mode & $\begin{array}{l}\text { Standard } \\
\text { deviation }\end{array}$ & $\begin{array}{l}\text { Teachers with } \\
\text { competency }\end{array}$ \\
\hline Knowledge of the characteristics and limitations of the institutional e-mail account & 4.61 & 5.00 & 0.76 & $90.32 \%$ \\
\hline Navigates in the site of Aerocivil & 3.45 & 4.00 & 0.77 & $54.84 \%$ \\
\hline Uses the ISOLUCION application to consult the institutional documents & 2.97 & 4.00 & 1.22 & $41.94 \%$ \\
\hline Uses the institutional website to consult the regulations of the Aerocivil & 3.55 & 4.00 & 1.03 & $70.97 \%$ \\
\hline Knowledge about the site SIGEP to search information about the staff & 3.65 & 5.00 & 1.28 & $61.29 \%$ \\
\hline
\end{tabular}


Table 6. Pedagogical aspects

\begin{tabular}{|c|c|c|c|c|}
\hline Competency & Mean & Mode & $\begin{array}{l}\text { Standard } \\
\text { deviation }\end{array}$ & $\begin{array}{l}\text { Teachers with } \\
\text { competency }\end{array}$ \\
\hline Use and promotion of computers in the classroom & 4.58 & 5.00 & 0.62 & $93.55 \%$ \\
\hline Use of multimedia slideshows as support material in the classroom & 3.68 & 4.00 & 0.70 & $67.74 \%$ \\
\hline Shares the rubrics with the students for internet search & 3.23 & 4.00 & 0.88 & $48.39 \%$ \\
\hline Promotes computer activities with the students & 4.10 & 5.00 & 0.94 & $74.19 \%$ \\
\hline $\begin{array}{l}\text { Proposes reflection and debates with teachers colleagues about the use of } \\
\text { computers and digital resources in training processes }\end{array}$ & 3.71 & 5.00 & 1.22 & $58.06 \%$ \\
\hline
\end{tabular}

Table 7. Communication aspects

\begin{tabular}{|c|c|c|c|c|}
\hline Competency & Mean & Mode & $\begin{array}{l}\text { Standard } \\
\text { deviation }\end{array}$ & $\begin{array}{c}\text { Teachers with } \\
\text { competency }\end{array}$ \\
\hline Communicates with friends and family through e-mail & 4.68 & 5.00 & 0.70 & $93.55 \%$ \\
\hline Communicates with students and colleagues through the institutional e-mail & 4.58 & 5.00 & 0.62 & $93.55 \%$ \\
\hline Participates in virtual communities related to my area & 2.68 & 3.00 & 1.14 & $19.35 \%$ \\
\hline Uses blogs to share experiences with students and colleagues & 2.39 & 1.00 & 1.26 & $22.58 \%$ \\
\hline Manages e-mail accounts through mobile devices & 3.81 & 5.00 & 1.22 & $58.06 \%$ \\
\hline
\end{tabular}

Table 8. Ethical aspect

\begin{tabular}{|c|c|c|c|c|}
\hline Competency & Mean & Mode & $\begin{array}{l}\text { Standard } \\
\text { deviation }\end{array}$ & $\begin{array}{c}\text { Teachers with } \\
\text { competency }\end{array}$ \\
\hline Practices respect to other people while communicating through the internet & 4.90 & 5.00 & 0.30 & $100 \%$ \\
\hline Promotes the ethical use of internet to the students & 3.77 & 4.00 & 0.62 & $74.19 \%$ \\
\hline Respects copyrights of the internet information & 3.68 & 4.00 & 0.79 & $61.29 \%$ \\
\hline Implements occupational regulations while using the computer and internet & 3.19 & 4.00 & 0.79 & $41.94 \%$ \\
\hline Reflects with colleagues and students about the risks of internet information & 3.35 & 3.00 & 0.88 & $45.16 \%$ \\
\hline
\end{tabular}

When considering communication skills, the respondents indicated a strong relationship between the development of this competence and the facilities and limitations of the educational center. Ethical competencies were considered a fundamental principle when communicating with other people via the Internet (100\%), whereas reflecting with colleagues and students about the risks of sharing internet information (45.16\%) and the implementation of occupational health standards for computer use (41.94\%) were areas given less attention. In this regard and as indicated by Salinas [18], the new role of teaching staff in ICT is emphasized, including the need to provide guidance in the use of databases, enhancement of the self-learning process through web browsing, and the need to serve as advisors and managers in the use of computer resources through promoting collaborative work.

\subsection{Strategies and actions to promote the use of ICT in training processes of the Center of Aeronautical Studies}

Results for this category were obtained from the focus group and the findings from the previous sections. The purpose of the focus group was to retrieve information about specific practices carried out that foster the use of ICT and innovation in the CEA. It was confirmed through the group, including the five teachers, that despite the limitations, teachers showed development of digital skills derived from three main factors:

1) The initiative of the teachers themselves.

2) A large number of professors being relatively new to the Center.

3) The majority of teachers also working in other educational institutions. 
The main strategy of adopting a specific ICT use policy at the Center of Aeronautical Studies should be accompanied by actions leading to improvements in infrastructure that ensure access to the Internet, as well the maintenance of an independent platform for training courses. The need to strengthen the educational resources area was identified by the focus group as being one of the most important actions required of the CEA. This should increaseing the support given to teachers by the instructional designers and technical staff for the development of materials and the implementation of a platform, such as Moodle or Blackboard, to deliver courses.

\section{Conclusions}

This research aimed to identify the current state of the policies of the Center of Aeronautical Studies of Colombia's Civil Aviation Authority Agency in relation to the use of ICT in the teaching-learning environment. It also sought to evaluate the digital competencies of the CEA teachers in training processes, as well as establishing educational strategies and actions to promote the development of digital competencies in CEA teaching staff. Rresearch with a quantitative approach and non-experimental descriptive design was conducted to analyze the use of information and communication technologies at the CEA. The training provided by the CEA and its current context within the aviation industry was identified, from the perspective of the teaching and managerial staff. Interviews with managers helped identify that policies have been established for the use of ICT in the business environment and for other operations, but not for training purposes within the CEA, which limits the use of ICTs by teachers and students. This is a factor that hinders the strengthening of digital competencies and does not facilitate the required transformation of the teaching-learning approach focused on know-how, to the competency-based approach, as recommended by the ICAO [6]. The result of the interviews and surveys, as well as the data obtained from conversation with the focus group, showed the need for a specific policy regarding the use of ICT in the CEA. According to the limitations expressed by the participants, the policy must guarantee continuous updating of the technological infrastructure, whether linked to or separate from the current civil aviation regulations, and there should be an interface facilitating communications between the Center of Aeronautical Studies and Colombia's Civil Aviation Authority. This flexibility is suggested through use of hardware and software, and through access to sources of information via the Internet, in order to develop higher thinking skills and innovation processes to solve problems [14].

The results from the survey questions, which were designed to establish the degree of competency in technical, educational, communicative and ethical aspects, indicated that, for the most part, CEA teachers showed meaningful advances in the development of digital competencies. It was also possible to note that, although a correlation was seen between the limitations set by the Aerocivil and the achieved development and facilities for ICT use, the development achieved was above what might be expected. Similarly, the participants' comments led to the conclusion that the digital capabilities of the CEA teachers were positively impacted on by the inclusion of more recently employed professors who also worked in other educational institutions, providing the opportunity to constantly improve their practice and to positively contribute to the working context.

Something to be emphasized in regard to the competencies developed by the teachers relates to the pedagogical aspects of understanding both the opportunities and challenges of ICT in an educational context, particularly in regard to personal productivity, participation in virtual communities, adhering to occupational health standards for computer use, and reinforcement of the ethical aspects of copyright and the risks of sharing information on the Internet [31]. Meanwhile, those areas that should be promoted relate to the design and implementation of learning environments using ICT to strengthen discipline knowledge and professional development, implementation of strategies to improve the Institutional Education Project, strengthening the development of strategies for collaborative work, joining learning networks, and encouraging analysis, synthesis and reflection on the opportunities, risks and responsibilities when using ICT [31].

The focus group suggested actions to improve the teacher-focused blended learning training courses, production of learning materials and a platform for administration of the courses, however, it is necessary to introduce a vision about the innovative potential of these tools. Educational strategies and actions will strengthen the migration process, from classroombased studying to virtual or blended course learning, as recommended by the ICAO in order to adopt the TRAINAIR competency-based approach. In this context, the teacher must take a leading role in innovation, as stated by UNESCO [26], creating new learning environments, redesigning the curriculum in an interdisciplinary way, participating in learning communities and generating new knowledge. 
Among the key recommendations from the study are:

- To establish a specific policy on the use of ICT in the Center of Aeronautical Studies, with the participation of principals, teachers and staff.

- To design a project to improve the technological infrastructure.

- To establish a strategy and training courses to strengthen the digital skills of teachers based on international guidelines, such as UNESCO.

- To determine specific quality criteria for the training process.

- To incorporate a specialist team to contribute to the educational development in the training process and the redesign of support material.

Further research is required involving the application of the instrument on students, which should complement the present findings on the development of digital skills in teachers and facilitate the adoption of comprehensive strategies, as recommended for aviation staff and employees by the International Civil Aviation Organization. It is also proposed to use this research as an example in order to promote academic investigation by teachers and students in aviation. This could encourage further studies with the intention of stimulating the development of innovative processes aimed at improving the training of air navigation personnel.

\section{References}

1. ICAO. Manual de Instrucción sobre factores humanos [Internet]. Document 9683 AN/950. 1998. [cited 2015 August 02]. Available from: <http://es.scribd.com/doc/ 40163919/DOC-9683-Factores-Humanos >

2. ICAO. Guía para la preparación de programas de Instrucción. TRAINAIR. Montreal. Canadá: Organización de Aviación Civil Internacional; 1991.

3. Moreira M. Introducción a la Tecnología Educativa. España: Universidad de la Laguna; 2009.

4. Sánchez B. Sistemas Aeroportuarios, Servicio Público e Iniciativa Privada [Internet]. CEPAL. 2011 [cited 2015 August 02]. Available from: < http://www.cepal.org/cgibin/getProd.asp? xml=/Transporte/noticias/bolfall/6/35276/ P35276.xml\&xsl=/publicaciones/ficha.xsl\&base =/ publicaciones/top_publicaciones.xslt $>$.

5. Avogadro M. Comunicación Aérea: Estrategia, NTIC y Seguridad. 2009. [cited 2015 August 05]. Available from: <http://www.razonypalabra.org.mx/comunicarte/2009/ enero.html $>$.

6. ICAO. Procedimientos para los servicios de navegación Aérea. Instrucción [Internet]. Document 9868. 2006 [cited 2015 August 02]. Available from: < http://www.techstreet. com/products $/ 1783647$ ?product id $=1783647 \&$ sid $=$ goog\& gclid=CPWKjo_mpLwCFczm7 $\bar{A}$ odfCUAjA > .

7. CAO. Comunicado de Prensa. El día de la aviación civil internacional de 2007, se centra en los beneficios del transporte aéreo en todo el mundo [Internet]. Montreal. 2007a [cited 2015 August 02]. Available from: < http://www. icao.int/secretariat/SecretaryGeneral/aviation_day/2007/ pio200712_s.pdf $>$.

8. OIT. La Aviación Civil y los cambios en su entorno laboral. Organización Internacional del Trabajo (OIT). Programa de estudios sectoriales GDFCAI/2013. 2013 [cited 2015 August 05]. Available from: <http://www.ilo.org/wcmsp5/ groups/public/...ed_dialogue/..-sector/documents/ meetingdocument/wcms_201283.pdf $>$.

9. Concepto Operacional de Gestión del Tránsito Aéreo Mundial [Internet]. Document 9854 AN/458. 2005 [cited 2015 August 05]. Available from: < http://www.icao.int/NACC/ Documents/Meetings/2012/ASBU/Referencia3.pdf $>$.

10. ICAO. Plan Mundial de Navegación Aérea. Document 9750 AN/953 [Internet]. 2007 [cited 2015 August 02]. Available from: < http://www.icao.int/publications/Documents/9750 cons_es.pdf $>$.

11. Proyecto Educativo Institucional. Centro de Estudios de Ciencias Aeronáuticas - CEA. 2015 [cited 2016 April 28]. $<$ http:/www.aerocivil.gov.co/Educacion/CEA/Documents/ PEI-Proyecto\%20Educativo\%20CEA.pdf $>$.

12. Rimari W. La innovación educativa: un instrumento de desarrollo. México: Universidad Autónoma de Anáhuac; 2011.

13. Barraza A. Una conceptualización comprensiva de la innovación educativa. Innovación Educativa. 2005; 5(28): e19-31.

14. Alemán L, Gómez-Zermeño MG, Parada E, Sáenz P. Alfa Kick Start. Estrategias extracurriculares para la enseñanza de la innovación. Nuevas formas de enseñar la innovación [Internet]. 2011 [cited 2015 August 03]. Available from: $<$ http://alfakickstart.files.wordpress.com/2011/04/itesm-pupsa-vf-estrategias-extracurriculares-para-la-ensec $3 b 1$ anzade-la-innovacic3b3n.pdf $>$.

15. Asociación Nacional de Universidades e Instituciones de Educación Superior. La Innovación en la Educación Superior [Internet]. México; 2004 [cited 2015 August 03]. Available from: <http://comitecurricularsistemas.wikispaces. com/file/view/INNOVACION_EN_LA EDUCACION SUPERIOR_ANUIES_MAYO $\overline{+} 200 \overline{4} \cdot \mathrm{pd} \overline{\mathrm{f}}>$.

16. Fullan, M. Los nuevos significados del cambio en educación. Barcelona, España: Ediciones Octaedro; 2002.

17. Moreira M. Innovación pedagógica con TIC y el desarrollo de las competencias informacionales y digitales. Revista Investigación en la escuela. 2008; 64: e5-18.

18. Salinas J. Innovación educativa y uso de las TIC. España: Universidad Internacional de Andalucía; 2008.

19 Domingo M, Fuentes M. Innovación Educativa: Experimentar con las TIC y reflexionar sobre su uso. Revista de Medios y Educación. 2010; 36: e171-180. Fullan M (2002). Los nuevos significados del cambio en educación. Barcelona, Spain: Ediciones Octaedro.

20 Delors J. La educación encierra un tesoro. Informe a la UNESCO de la Comisión Internacional sobre la educación para el siglo XXI. Madrid, Spain: Santillana-UNESCO; 1996.

21. Tobón S. Formación basada en competencias. Pensamiento complejo, diseño curricular y didáctica. Bogotá, Colombia: ECOE Ediciones; 2004.

22. Tobón S, Pimienta J, García J. Secuencias didácticas. Aprendizaje y evaluación de competencias. México: Pearson; 2010.

23. Lozano A, Herrera J. Diseño de programas educativos basados en competencias. Monterrey. México: Editorial Digital del Tecnológico de Monterrey; 2012. 
24. Gómez-Zermeño MG, Alemán L. Administración de proyectos de capacitación basados en tecnología. Monterrey, México: Editorial Digital del Tecnológico de Monterrey; 2011.

25. Carnoy M. ICT in education: Possibilities and challenges. Barcelona, Spain: Universidad Oberta de Catalunya; 2004. p. 1.

26. UNESCO. Estándares de competencia en TIC para docentes [Internet]. Paris: Organización de las Naciones Unidas para la Educación, la Ciencia y la Cultura. 2008 [cited 2015 August 02]. Available from: <http://www.oei.es/tic/ UNESCOEstandaresDocentes.pdf $>$.

27. Bondarenko N. Acerca de las definiciones de la calidad en educación. Revista Educere. 2007; 11(39), e613-621.

28. Aguerrondo I. Los desafíos de la política educativa relativos a las reformas de la formación docente. En AAVV, Maestros en América latina: Nuevas perspectivas sobre su formación y desempeño. Santiago de Chile: PREAL-CINDE; 2004. p. $97-142$.

29. Garbanzo G. Calidad y equidad de la educación superior pública. Aspectos por considerar en su interpretación. Educación. 2007; 31(2): e11-27.

30. Universidad Nacional de Colombia. Los indicadores de equidad en el sistema educativo: una aproximación teórica [Internet]. 2006 [cited 2015 August 02]. Available from: <http://www.mineducacion.gov.co/1621/articles-124037 archivo_pdf.pdf $>$.

31. Ministerio de Educación Nacional [MEN]. Sistema Nacional de Indicadores Educativos para los niveles Preescolar, Básica y Media en Colombia [Internet]. 2013 [cited 2015 August 02]. Available from: < http://www.mineducacion. gov.co/1621/articles-329021 archivo pdf indicadores educativos_enero_2014.pdf >.
32. Consejo Nacional de Acreditación [CNA]. Lineamientos para la Acreditación de Programas [Internet]. 2003. [cited 2015 August 02]. Available from: < http://www.upbbga.edu. $\mathrm{co} /$ nuestraupb/LineamientosCNA2003.pdf $>$.

33. Consejo Nacional de Acreditación [CNA]. Lineamientos para la Acreditación Institucional [Internet]. 2006. [cited 2015 August 02]. Available from: <http://cms-static. colombiaaprende.edu.co/cache/binaries/articles-186359 lineamientos_3.pdf?binary rand $=2342>$.

34 Orozco J, Olaya A, Villate V. ¿Calidad de la educación o educación de calidad? Una preocupación más allá del mercado. Revista Iberoamericana de Educación. 2009; 55: e161-181.

35. Rodríguez W. El Concepto de calidad educativa: una mirada crítica desde el enfoque histórico cultural. Revista INIE. 2010; $10(1):$ e $1-28$.

36. Hernández R, Fernández C, Baptista P. Metodología de la investigación. México: McGraw Hill; 2006.

37. Aeronáutica Civil de Colombia. Centro de Estudios de Ciencias Aeronáuticas - CEA. 2015 [cited 2015 December 28]. <http://www.aerocivil.gov.co/Educacion/CEA/Paginas/ Inicio.aspx $>$.

38. Valenzuela JR, Flores M. Fundamentos de Investigación Educativa. Monterrey, México: Editorial Digital del Tecnológico de Monterrey; 2012.

39. Prendes M, Castañeda L, Gutiérrez I. Competencias para el uso de TIC de los futuros maestros. Comunicar. 2010; 35 : e175-182.

40. Aeronáutica Civil de Colombia. Modelo de Seguridad de la Información. Resolución 04228 de 2012. 